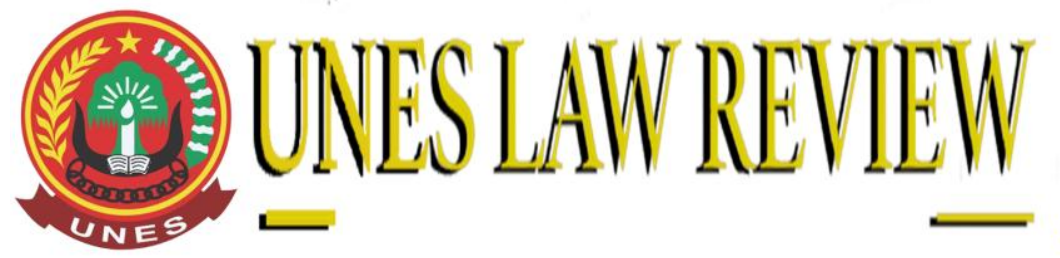

$+6281365118590$

$+6281365118590$

https://review-unes.com/ (7)

uneslawreview@gmail.com @.

DOI: https://doi.org/10.31933/unesrev.v4i3

Diterima: 24/02/2022, Diperbaiki: 25/02/2022, Diterbitkan: 01/03/2022

\title{
ANALISIS YURIDIS PERSEROAN PERORANGAN DITINJAU DARI UNDANG-UNDANG CIPTA KERJA DAN UNDANG-UNDANG PERSEROAN TERBATAS
}

\author{
Sylvia Putri ${ }^{1}$, David Tan ${ }^{2}$ \\ 1) Fakultas Hukum, Universitas Internasional Batam, Indonesia. \\ Email: 1951120.sylvia@uib.edu \\ 2) Fakultas Hukum, Universitas Internasional Batam, Indonesia. \\ Email: david.tan@uib.edu
}

Corresponding Author: Sylvia Putri

\section{ABSTRACT}

The current crisis situation, due to the Covid-19 pandemic, has caused the government to enact the Job Creation Law as an effort to advance the economy, in particular, micro and small businesses. The existence of the Job Creation Law expands the concept of a limited liability company with the recognition of a new legal entity, namely an individual company. The existence of an individual company gave birth to a number of contradictions in the basic concept of a limited liability company. This normative juridical research will discuss the regulation of micro and small business criteria based on the Job Creation Law and the limited liability company law as well as legal loopholes and proposed improvements. This study aims to determine the arrangements related to individual companies. The results of the study indicate that the legal basis for individual companies still has legal loopholes so that the government plays an important role in strengthening the regulation.

Keywords: Individual Limited Liability Company, Micro and Small Enterprises (MSEs), Job Creation Law

\section{ABSTRAK}

Situasi krisis saat ini, akibat adanya pandemi Covid-19 menyebabkan pemerintah menetapkan UU Cipta Kerja sebagai salah satu upaya untuk memajukan pembangunan ekonomi khususnya, usaha mikro dan kecil. Kehadiran UU Cipta Kerja memperluas konsep perseroan terbatas dengan diakuinya badan hukum baru, yaitu Perseroan Perorangan. Hadirnya perseroan perorangan melahirkan sejumlah kontradiksi dalam konsep dasar perseroan terbatas. Penelitian yang bersifat yuridis normatif ini, akan membahas tentang pengaturan perseroan kriteria usaha mikro dan kecil berdasarkan UU Cipta Kerja dan UU PT serta celah hukum dan usulan mengenai perbaikan. Penelitian ini bertujuan untuk mengetahui pengaturan terkait perseroan perorangan. Hasil 
penelitian menunjukkan bahwa payung hukum untuk perseroan perorangan masih terdapat celah hukum sehingga pemerintah berperan penting dalam memperkuat pengaturan tersebut.

Kata Kunci: Perseroan Perorangan, Usaha Mikro dan Kecil, UU Cipta Kerja

\section{PENDAHULUAN}

Pandemi Covid-19 berdampak signifikan terhadap penurunan pembangunan ekonomi di Indonesia, bahkan dalam kondisi global. ${ }^{1}$ Adanya Undang-Undang Nomor 11 Tahun 2020 tentang Cipta Kerja (selanjutnya disebut UU Cipta Kerja) dinilai dapat mendukung dan membantu dalam pertumbuhan ekonomi. UU Cipta Kerja bertujuan untuk menjadi stimulus positif bagi pertumbuhan dan perbaikan ekonomi nasional dengan menggerakan seluruh sektor untuk mendorong pertumbuhan ekonomi mencapai 5.7\% - 6\% melalui penciptaan lapangan kerja yang berkualitas seluas-luasnya, peningkatan investasi, peningkatan konsumsi, peningkatan produktivitas dan peningkatan upah sehingga dapat mengikat daya beli dan konsumsi. ${ }^{2}$ Seiring dengan perkembangan zaman ada beberapa norma yang dinilai dan dianggap tidak lagi sesuai dengan situasi dan kondisi kini serta merugikan kepentingan masyarakat banyak sehingga adanya urgensi untuk pemangkasan serta penyederhanaan Undang-Undang. ${ }^{3}$ Hadirnya UU Cipta Kerja menyederhanakan puluhan regulasi menjadi satu Undang-Undang yang khusus, sehingga dapat menjadi jalan pintas untuk menyelaraskan kebijakan dan perampingan regulasi di Indonesia. ${ }^{4}$

Sehubungan dengan UU Cipta Kerja, pemerintah berharap para pelaku usaha tidak lagi mengalami kendala dalam membangun usahanya. Sebelumnya, para pelaku usaha harus berhadapan dengan peraturan perundang-undangan yang tumpang tindih terkait pelaksanaan perizinan. Bank dunia dan International Finance Corporation (IFC) memposisikan Indonesia di peringkat 166 dunia dalam hal kemudahan berusaha, menimbang dari proses yang begitu ketat dan panjang. Jika dibandingkan dengan lima rata-rata OECD, pengurusan pendirian badan usaha di Indonesia rata-rata membutuhkan waktu kurang lebih 47 hari untuk menyelesaikannya. ${ }^{5}$ Maka dari itu, dalam hal mendukung kemudahan berusaha, khusunya Usaha Mikro dan Kecil (UMK) pemerintah membentuk badan hukum baru berupa Perseroan Perorangan dengan tanggung jawab terbatas.

Mengingat, UMK merupakan kelompok pelaku ekonomi terbesar dalam perekonomian Indonesia dan terbukti menjadi katup pengaman dalam perekonomian Indonesia, serta menjadi

\footnotetext{
${ }^{1}$ Hanoatubun, S. (2020). Dampak Covid-19 terhadap Prekonomian Indonesia. EduPsyCouns: Journal of Education, Psychology and Counseling, 2(1), 146-153. hlm. 151.

${ }^{2}$ Prabu, A., Harahap, I. N., Ernasari, N., Primagani, T., Nirpana, B., Andriyas, I., \& Susanto, S. (2020). Kemudahan Berusaha Dalam Cluster Omnibus Law. Jurnal Lex Specialis, 1(2), hlm. 172.

${ }^{3}$ Matompo, O. S. (2020). Konsep Omnibus Law Dan Permasalahan Ruu Cipta Kerja. Rechtstaat Nieuw, 5(1). hlm. 23.

${ }^{4}$ Arief, A., \& Ramadani, R. (2021). Omnibus Law Cipta Kerja dan Implikasinya Terhadap Konsep Dasar Perseroan Terbatas. Al-Adalah: Jurnal Hukum dan Politik Islam, 6(2), 106-120. hlm. 107.

${ }^{5}$ Ariani, N. V., \& Narindrani, M. L. F. (2021). Legal Aspect of Individual Company for Micro and Small Business in Omnibus Law on Job Creation. In 2nd International Conference on Law and Human Rights 2021 (ICLHR 2021) (pp. 1-7). Atlantis Press. hlm. 2.
} 
dinamisator pertumbuhan ekonomi pasca krisis ekonomi. ${ }^{6}$ UMK berperan penting dalam pertumbuhan ekonomi karena merupakan tulang punggung perekonomian negara, hal ini didukung dengan jumlahnya yang mencapai $99,99 \%$ dari total pelaku usaha dan kontribusinya terhadap Produk Domestik Bruto (PDB) mencapai hingga 61,07\% serta penyerapan tenaga kerja Indonesia hingga $97 \% .^{7}$ UMK juga memiliki resistansi yang lebih baik terhadap krisis karena tenaga kerja dan struktur organisasi yang lebih fleksibel menyesuaikan dengan keadaan kini ${ }^{8}$ Sehingga dengan adanya Perseroan Perorangan diyakini dapat membantu UMK serta memberi jalur keluar bagi masyarakat dengan modal terbatas. Pemerintah juga berpendapat bahwa Perseroan Perorangan dapat memberikan terobosan baru serta payung hukum bagi UMK dan koperasi dengan kemudahan, perlindungan serta pemberdayaan yang diberikan.

Secara keseluruhan, pemerintah optimis bahwa konsep tersebut memberikan manfaat serta keuntungan bagi UMK, karena dipandang adanya kelonggaran yang diberikan seperti pemisahan harta dengan perseroan, kemudahan akses perbankan dan kemudahan dalam melakukan perikatan dengan pihak ketiga. Kemudahan dalam proses registrasi dengan hasil luaran berupa sertifikat Perseroan Perorangan akan memberikan manfaat yang signifikan untuk para pelaku usaha. Akan tetapi, seberapa siapkah perangkat hukum di Indonesia dalam menanggulangi kekurangan dan menjaga keberlanjutannya dikemudian hari. Faktanya, Peluang terjadinya konflik kepentingan di Perseroan Terbatas yang didirikan oleh 2 (dua) orang sangat tinggi. Sehingga tidak menutup kemugkinan Perseroan Terbatas yang didirikan oleh 1 (satu) orang ini mengalami hal yang relevan mengingat pemegang saham yang juga menjabat sebagai anggota direksi. ${ }^{9}$ Sehingga apakah dengan kemudahan yang diberikan dapat menjadi pemicu untuk timbulnya konflik di kemudian hari.

Sebelumnya penulis telah menguraikan latar belakang masalah, maka dari uraian masalah tersebut penulis tertarik untuk melakukan kajian lebih dalam mengenai Perseroan Perorangan ditinjau dari Undang-Undang yang bersangkutan. Urgensi tulisan ini dikarenakan Perseroan Perorangan didirikan oleh para pelaku usaha UMK yang juga merupakan jalan keluar dalam mendukung pertumbuhan ekonomi nasional. Penelitian ini bertujuan untuk mengetahui Perseroan Perorangan dalam sudut pandang hukum dikaitkan dengan Undang-Undang yang relevan dan untuk mengetahui kepastian hukum Perseroan Perorangan akibat UU Cipta Kerja yang inkonstitusional. Demikian dapat dirincikan beberapa pokok permasalahan yang akan diangkat dalam pembahasan ini, yakni sebagai berikut (1) Bagaimana Analisis Yuridis Perseroan

\footnotetext{
${ }^{6}$ Sulfati, A. (2018). Efektivitas Pengembangan Usaha Mikro Di Indonesia. Jurnal Aplikasi Manajemen, Ekonomi dan Bisnis, 2(2), 59-69. hlm. 59.

7 Kementerian Koperasi dan Usaha Kecil dan Menangah (UKM). Perkembangan Data Usaha Mikro, Kecil, Menengah (UMKM) dan Usaha Besar (UB) tahun 2017-2018. http://www.depkop.go.id/uploads/laporan/1580223129_PERKEMBANGAN\%20DATA\%20USAHA\%20MIKRO, \%20KECIL, \%20MENENGAH\%20(UMKM)\%20DAN\%20USAHA\%20BESAR\%20(UB)\%20TAHUN\%202017\% 20-\%202018.pdf, Diakses pada 12 Februari 2022.

${ }^{8}$ Abbas, D. (2018). Pengaruh modal usaha, orientasi pasar, dan orientasi kewirausahaan terhadap kinerja ukm kota makassar. Jurnal Minds: Manajemen Ide Dan Inspirasi, 5(1), 95-112. hlm. 96.

9 Jaya, F. (2021). Potensi Konflik Kepentingan dalam Pendirian Badan Hukum Perorangan Pasca Revisi UndangUndang Perseroan Terbatas dalam Omnibus Law. Kosmik Hukum, 21(2), 115-123. hlm. 116.
} 
Perorangan Ditinjau Dari UU Cipta Kerja dan UU Perseroan Terbatas? dan (2) Bagaimana Kepastian Hukum Perseroan Perorangan akibat dari UU Cipta Kerja yang Inkonstitusional?

\section{METODE PENELITIAN}

Penelitian artikel ini menerapkan jenis penelitian berupa penelitian hukum yuridis normatif (doctrinal research). Penelitian hukum yuridis normatif (doctrinal research) dilakukan dengan mempelajari dan menelaah suatu topik permasalahan dengan data sekunder untuk menemukan jawabannya. Data sekunder adalah data yang diperoleh secara tidak langsung dari bahan kepustakaan atau literatur yang ada hubungannya dengan objek penelitian. ${ }^{10}$ Data sekunder yang diperoleh dari bahan pustaka, mencakup badan hukum primer, sekunder dan tersier untuk menganalisis permasalahan hukum dalam tulisan ini. Penelitian hukum yuridis normatif (doctrinal research) melibatkan penelitian terhadap asas-asas hukum, sistematika hukum, taraf sinkronisasi hukum, perbandingan hukum dan sejarah hukum. ${ }^{11}$

Pengumpulan data untuk pemecahan masalah dilakukan dengan penelitian kepustakaan (library research), yang lalu dianalisis secara kualitatif. Analisis kualitatif yakni analisis data yang bersumber dari bahan hukum bertumpu pada peraturan perundang-undangan, doktrin, prinsip hukum, pendapat pakar, konsep, teori dan pandangan peneliti sendiri. Terakhir, menyusun bahan-bahan yang terkumpul menjadi data hukum yang dapat menjawab permasalahan yang telah diuraikan sebelumnya. Penelitian ini menggunakan pendekatan Undang-Undang (statue approach) dan pendekatan perbandingan (comparative approach). Metode analisis penelitian ini dilakukan agar penulis dapat mencapai suatu konklusi yang benar.

\section{HASIL DAN PEMBAHASAN}

\section{Perseroan Perorangan Ditinjau dari UU Cipta Kerja dan UU Perseroan Terbatas}

UU Cipta Kerja resmi diundangkan pada 2 November 2020, kehadiran UU Cipta Kerja sudah menarik kembali dua peraturan dan merevisi berbagai ketentuan perundang-undangan di berbagai sektor yang paling sedikit sudah merevisi 80 Undang-Undang lain. Salah satu UndangUndang yang terpengaruh adalah Undang-Undang Nomor 40 Tahun 2007 Tentang Perseroan Terbatas (selanjutnya disebut UU PT), yang mengatur norma dan praktik bisnis di Indonesia. ${ }^{12}$ Pasal 109 dalam UU Cipta Kerja mengatur sejumlah pasal yang mengubah beberapa ketentuan di dalam UU PT. Ketentuan perubahan terkait Perseroan Terbatas di dalam UU Cipta Kerja kemudian dipertegas kembali dalam Peraturan Pemerintah Nomor 8 Tahun 2021 tentang Modal Dasar Perseroan Serta Pendaftaran Pendirian, Perubahan, Dan Pembubaran Perseroan Yang Memenuhi Kriteria Untuk Usaha Mikro Dan Kecil (selanjutnya disebut PP 8/2021).

\footnotetext{
${ }^{10}$ Ishaq, I. (2017). Metode Penelitian Hukum dan Penulisan Skripsi, Tesis, serta Disertasi. Bandung: Alfabeta., hlm. 67.

${ }^{11}$ Tan, D. (2021). Metode Penelitian Hukum: Mengupas Dan Mengulas Metodologi Dalam Menyelenggarakan Penelitian Hukum. Nusantara: Jurnal Ilmu Pengetahuan Sosial, 8(8), 2463-2478. hlm. 2468.

${ }^{12}$ Arief, A., \& Ramadani, op. cit. hlm 112.
} 


\section{Perluasan Konsep Perseroan: Hadirnya Perseroan Perorangan sebagai Badan Hukum} ialah:

"Perseroan Terbatas, yang selanjutnya disebut Perseroan, adalah badan hukum yang merupakan persekutuan modal, didirikan berdasarkan perjanjian, melakukan kegiatan usaha dengan modal dasar yang seluruhnya terbagi dalam saham dan memenuhi persyaratan yang ditetapkan dalam undang-undang ini serta peraturan pelaksanaannya."

Pasca UU Cipta Kerja, perseroan telah mengalami perluasan konsep yang telah diperkenalkan dengan istilah yang baru yaitu Perseroan Perorangan. Pengertian dari Perseroan Perorangan berdasarkan pada Pasal 1 angka 1 UU PT yang telah mengalami perubahan makna berdasarkan Pasal 109 angka 1 UU Cipta Kerja, ialah:

"Perseroan Terbatas, yang selanjutnya disebut Perseroan, adalah badan hukum yang merupakan persekutuan modal, didirikan berdasarkan perjanjian, melakukan kegiatan usaha dengan modal dasar yang seluruhnya terbagi dalam saham atau badan hukum perorangan yang memenuhi kriteria Usaha Mikro dan Kecil sebagaimana diatur dalam peraturan perundang-undangan mengenai Usaha Mikro dan Kecil."

Penambahan kalimat "badan hukum perorangan yang memenuhi kriteria Usaha Mikro dan Kecil sebagaimana diatur dalam peraturan perundang-undangan mengenai Usaha Mikro dan Kecil" yang memberikan pengertian bahwa adanya aturan baru yang mengesahkan sebuah UMK dengan pemegang saham sebanyak 1 (satu) orang untuk mendirikan sebuah badan hukum. ${ }^{13}$

UU Cipta Kerja tidak memberikan definisi tersendiri untuk Perseroan Perorangan. Setelah adanya badan hukum baru, seyogianya definisi mengenai Perseroan Perorangan juga diuraikan secara jelas dan tegas sehingga tidak menimbulkan salah penafsiran. Hal tersebut juga karena konsep dari Perseroan Terbatas itu sendiri sangat berbanding terbalik dengan Perseroan Perorangan dilihat dari aspek kepemilikan saham serta organ perseroan. Sehingga adanya penggabungan tersebut dapat menimbulkan salah kaprah.

\section{Pendirian Perseroan Perorangan: Ketiadaan Akta Notaris}

Berdasarkan definisi yang diamanatkan dalam UU Cipta Kerja, maka terdapat 2 (dua) jenis perseroan dengan 2 (dua) cara pendirian yang berbeda. Pertama adalah Perseroan Terbatas, tata cara pendirian dan pengumuman perusahaan ternyata dalam Pasal 7 UU PT. Sebelumnya telah di tegaskan bahwa perseroan didirikan oleh 2 (dua) orang atau "lebih" dengan akta notaris yang dibuat dalam Bahasa Indonesia. Tujuannya agar dapat dikendalikan dan dikontrol oleh 2 (dua) orang atau lebih, terutama dalam menjalankan fungsi check and balances dalam pengambilan keputusan. Apabila syarat minimal 2 (dua) orang tidak terpenuhi akibatnya segala perbuatan hukum dan kerugian perusahaan menjadi tanggung jawab pendiri atau pemegang saham secara pribadi serta kondisi tersebut bertentangan

\footnotetext{
13 Aprilia, I. S. (2020). Aspek Hukum Pemegang Saham dalam Perseroan dengan Satu Pemegang Saham (Single Share-holder)(Studi Komparasi Indonesia dengan China). SUPREMASI: Jurnal Hukum, 3(1), 1-14. hlm. 8.
} 
dengan UU PT. Akta notaris menjadi hal yang penting karena merupakan sebuah akta otentik yang berperan dalam menciptakan kepastikan hukum serta dapat digunakan sebagai alat bukti yang kuat dan penuh di mata hukum karena sifatnya yang mengikat dan sempurna. ${ }^{14}$ Pasca UU Cipta Kerja, Pasal 7 UU PT diubah dengan diberi pengecualian untuk Perseroan Perorangan.

Kedua ialah Perseroan Perorangan, perusahaan jenis ini dapat didirikan oleh satu orang tanpa harus mencari pasangan bisnis asalkan memenuhi kriteria UMK. Akibatnya, perusahaan didirikan dan dikendalikan oleh satu orang sehingga kemungkinan adanya penipuan lebih besar karena dapat memanfaatkan tanggung jawab yang terbatas terhadap pihak ketiga. ${ }^{15}$ Perseroan Perorangan dalam proses pendiriannya tidak perlu melalui perjanjian dan akta notaris. Hal ini di atur dalam Pasal 153A UU Cipta Kerja dan dipertegas dalam Pasal 6 PP 8/2021.

Pasal 153A Undang-Undang Cipta Kerja menyebutkan bahwa:

a. Perseroan yang memenuhi kriteria usaha mikro dan kecil dapat didirikan oleh 1 (satu) orang;

b. Pendirian Perseroan untuk usaha mikro dan kecil sebagaimana dimaksud pada ayat (1) dilakukan berdasarkan surat pernyataan pendirian yang dibuat dalam Bahasa Indonesia;

c. Ketentuan lebih lanjut mengenai pendirian Perseroan untuk usaha mikro dan kecil diatur dengan Peraturan Pemerintah.

Pasal 6 PP 8/2021 menyebutkan bahwa:

a. Perseroan perorangan didirikan oleh Warga Negara Indonesia dengan mengisi Pernyataan Pendirian dalam bahasa Indonesia.

b. Warga Negara Indonesia sebagaimana dimaksud pada ayat (1) harus memenuhi persyaratan:

1) berusia paling rendah 17 (tujuh belas) tahun; dan

2) cakap hukum.

c. Perseroan perorangan memperoleh status badan hukum setelah didaftarkan kepada Menteri dan mendapatkan sertifikat pendaftaran secara elektronik.

d. Perseroan perorangan yang telah memperoleh status badan hukum sebagaimana dimaksud pada ayat (3) diumumkan oleh Menteri dalam laman resmi Direktorat Jenderal yang menyelenggarakan tugas dan fungsi di bidang administrasihukum umum.

Ketentuan Pasal 153A Undang-Undang Cipta Kerja dan Pasal 6 PP 8/2021 menjelaskan bahwa pendirian perseroan UMK didirikan tanpa melalui akta notaris melainkan hanya membuat surat pernyataan pendirian yang memuat maksud dan tujuan, kegiatan usaha, modal dasar, dan keterangan lain yang berkaitan dengan pendirian perseroan terbatas. Surat pernyataan pendirian tersebut kemudian didaftarkan secara elektronik kepada Kementerian Hukum dan HAM. Secara khusus, adanya kemudahan yang diberikan

\footnotetext{
${ }^{14}$ Isnaeni, D. (2021). Peran Notaris Dalam Pendirian Pt Usaha Mikro Dan Kecil. Jurnal Hukum Dan Kenotariatan, 5(2). hlm. 208.

${ }^{15}$ Isnaeni, D., Ibid. hlm 212.
} 
pemerintah Indonesia memberikan pendapat dan tanggapan yang beragam. Dari sudut pandang para pelaku usaha UMK, kebijakan tersebut sangat membantu dikarenakan biaya yang relatif lebih murah dibandingkan dengan pendirian Perseroan Terbatas serta jangka waktu menjadi sebuah badan hukum yang relatif lebih singkat. ${ }^{16}$ Sedangkan dari sudut pandang lain, hal ini mengakibatkan hilangnya jangkauan notaris dalam proses pendirian sebuah badan hukum, akibatnya tidak adanya pelaksanaan dan pengawasan dari notaris. ${ }^{17}$

3. Modal

Dalam menjalankan sebuah usaha, modal merupakah sebuah aspek penting bagi suatu perusahaan khususnya dalam hal pendirian perusahaan, karena dalam mendirikan sebuah perusahaan pasti perlu di pertimbangan modal usaha sehingga dapat memenuhi kebutuhan setiap kegiatan dan aktivitas yang dijalankan perusahaan. Pelaku usaha yang hendak mendirikan Perseroan Perorangan harus memenuhi beberapa syarat yang ditentukan oleh pemerintah, antara lain: (1) Syarat usaha mikro, modal usaha minimal Rp. 1.000.000.000.(satu miliar Rupiah) dan hasil penjualan tahunan tidak melebihi Rp. 2.000.000.000.- (dua miliar Rupiah) serta (2) Syarat usaha kecil, modal usaha dalam jangka Rp. 1.000.000.000.(satu miliar Rupiah) hingga Rp. 5.000.000.000.- (lima miliar Rupiah) dan hasil penjualan tahunan lebih dari Rp. 2.000.000.000.- (dua miliar Rupiah) hingga Rp. 15.000.000.000. (lima belas miliar Rupiah). Modal usaha tidak termasuk dengan tanah dan bangunan tempat usaha. Hal ini tecantum dalam Pasal 35 Peraturan Pemerintah Nomor 7 Tahun 2021 tentang Kemudahan, Pelindungan, Dan Pemberdayaan Koperasi Dan Usaha Mikro, Kecil, Dan Menengah (selanjutnya disebut PP 7/2021).

Nilai nominal kriteria modal usaha maupun hasil penjualan dapat berubah sesuai dengan kondisi perekonomian. Penentuan ini penting sebagai tolak ukur dan penentu bagi pendiri usaha perorangan mengenai jenis usaha apa yang akan dijalankan serta dapat dijadikan peralatan pegawasan untuk pemerintah terkait status usaha. ${ }^{18}$ Rentang nilai modal usaha dan hasil penjualan untuk UMK sudah diuraikan secara jelas dalam Peraturan Pemerintah. Lain halnya dengan perseroan terbatas, dalam Pasal 32 ayat (1) UU PT dijelaskan bahwa besaran modal dasar pendirian perseroan terbatas paling sedikit Rp. 50.000.000.- (lima puluh juta Rupiah), lebih besarnya modal dasar diserahkan sepenuhnya kepada para pendiri dan pemegang saham berdasarkan kesepakatan para pihak yang dituangkan dalam akta notaris dan disahkan oleh Kementerian Hukum dan HAM. Keserasian antara Perseroan Terbatas dan Perseroan Perorangan dapat dilihat dari modal disetor. Modal dasar perseroan harus ditempatkan dan disetor minimal 25\% (dua puluh lima persen) dari modal dasar yang dibuktikan dengan bukti penyetoran yang sah.

${ }^{16}$ Gloria, M. (2021). Kepailitan Perseroan Perorangan dalam Undang-Undang Cipta Kerja. Jurnal Panorama Hukum, 6(1), 24-31. hlm. 26.

17 Zulhidayat, M., \& Aslamiyah, M. (2021). Pertanggungjawaban Pemegang Saham Perseroan Perorangan dalam Hal Perseroan Perorangan Mengalami Kerugian Berdasarkan UU No. 11 Tahun 2020 Tentang Cipta Kerja. Rechtsregel: Jurnal Ilmu Hukum, 4(1), 119-133. hlm. 127.

18 Pangesti, S. (2021). Penguatan Regulasi Perseroan Terbatas Perorangan Usaha Mikro Dan Kecil Dalam Mendukung Pemulihan Ekonomi Masa Pandemi Covid-19. Jurnal Rechts Vinding: Media Pembinaan Hukum Nasional, 10(1), 117. hlm. 123. 


\section{Direksi Perseroan}

Dalam Perseroan Terbatas dan Perseroan Perorangan tidak terdapat perbedaan organ perseroan hal ini dapat dilihat jika menelaah UU PT, UU Cipta Kerja dan PP 8/2021 tidak ada pengaturan mengenai perubahan susunan organ. ${ }^{19}$ Dalam pengaturan mengenai organ perseroan dibagi menjadi 3 (tiga) kategori yaitu: Direksi, Dewan Komisaris dan RUPS. Setiap organ menjalankan fungsinya masing-masing serta memilik hak dan kewajiban yang berbeda-beda dalam rangka mencapai tujuan perusahan. Hubungan antara Direksi, Dewan Komisaris, dan RUPS adalah sederajat. Masing-masing organ memiliki tugas dan wewenang yang tidak boleh dicampuri oleh organ yang satu terhadap yang lain. ${ }^{20}$ Tugas direksi dalam Perseroan Perorangan diatur dalam UU Cipta Kerja yaitu menjalankan perseroan sesuai dengan maksud dan tujuan perseroan serta wajib untuk membuat laporan keuangan.

Kewajiban dalam pelaporan keuangan agar pemerintah dapat mengawasi dan memantau perihal keuangan perusahaan dan juga dari laporan keuangan dapat diketahui status usahanya. Berbeda halnya dengan direksi dalam perseroan terbatas, tugas dan wewenanganya diuraikan secara jelas dan tegas dalam UU PT sehinga terlihat jelas batasan yang diperbolehkan dan tidak diperbolehkan. Awal mula konsep didirikan Perseroan Terbatas dengan minimal 2 (dua) orang yang masing-masing menjabat sebagai direktur dan komisaris tentu sudah diperkirakan dengan matang akan tugas dan wewenang masing-masing pihak. Direktur memimpin perusahaan dan komisaris mengawasi jalannya perusahaan sehingga adanya pembatasan kekuasaan. Tugas dan tanggung jawab Dewan Komisaris lebih jelasnya diatur dalam UU PT yaitu melakukan pengawasan secara umum atas kebijakan jalannya pengurusan perseroan sesuai anggaran dasar, fungsi nasihat kepada Direksi dalam tugasnya mengurus perseroan, memberikan persetujuan atau bantuan kepada Direksi dalam melakukan perbuatan hukum tertentu, dan fungsi pengurusan Perseroan dalam keadaan darurat. $^{21}$ Sehingga apabila jabatan komisaris dihilangkan berakibat hilangnya pengawasan dalam perusahaan yang dapat mengakibatkan salahnya gunanya kekuasaan.

\section{Perubahan Pernyataan Pendirian Perseroan}

Perusahaan berjalan seiring dengan waktu pasti akan melakukan perubahan. Dalam pasal 153C UU Cipta Kerja, menjelaskan bahwa:

"Perubahan pernyataan pendirian Perseroan untuk Usaha Mikro dan Kecil sebagaimana dimaksud dalam Pasal 153A ditetapkan oleh RUPS dan diberitahukan secara elektronik kepada Menteri."

Berdasarkan Pasal 153C UU Cipta Kerja, menjelaskan perubahan Perseroan Perorangan ditetapkan oleh RUPS dan diberitahukan kepada Kementerian Hukum dan HAM. Penggunaan kata "RUPS" dalam Pasal 153C dinilai kurang tepat dalam Perseroan

\footnotetext{
${ }^{19}$ Jaya, F., op. cit. hlm 121.

${ }^{20}$ Hardiyono, Y. W. (2021). Keabsahan dan Akibat Hukum Pendirian Perseroan Mikro dan Kecil yang didirikan Berdasarkan Undang-Undang Nomor 11 Tahun 2020 Tentang Cipta Kerja. Dinamika: Jurnal Ilmiah Ilmu Hukum, 27(8), 1086-1101. hlm. 1097.

21 Manurung, O. T. (2016). Tugas Dan Tanggung Jawab Dewan Komisaris Sebagai Organ Perseroan Terbatas Menurut Undang Nomor 40 Tahun 2007. Lex Privatum, 4(7). hlm. 60.
} 
Perorangan karena tidak ada pemegang saham lain selain daripada pendiri. RUPS yang dihadiri oleh satu orang dalam Perseroan Perorangan tidak dapat memenuhi kewajiban sesuai dengan prinsip Perseroan Terbatas yang diatur dalam UU PT. Hal ini dikarenakan tidak ada kuorum dan musyawah mufakat yang diambil dalam RUPS. RUPS seharusnya memuat hasil musyawarah dan voting dari para pemegang saham yang dituangkan dalam akta notaris. Namun hal tersebut juga tidak bertentangan apabila RUPS dihadiri 1 (satu) orang sebagaimana ternyata dalam Pasal 90 UU PT. $^{22}$

RUPS adalah organ dalam suatu perseroan terbatas dimana forum ini memutuskan hal-hal penting dalam suatu perusahaan, sehingga pelaksanannya menjadi penting. RUPS merupakan media bagi seluruh pemegang saham dan pengurus perseroan untuk mengevaluasi dan membawa perusahaan tersebut berjalan dengan baik dan mewujudkan tujuan perusahaan. Filosofi dalam Perseroan Terbatas juga menyatakan bahwa dengan penuh itikad yang baik maka pemegang saham dan pengurus perseroan bertindak untuk kepentingan perseroan. ${ }^{23}$ Sehingga apabila RUPS dihadiri oleh satu orang yang bertindak sebagai pendiri sekaligus pemegang saham hal ini merujuk kepada adanya hak istimewa yang diberikan.

\section{Pemegang Saham Perseroan dan Pertanggungjawabannya}

Konsep pertanggungjawaban Perseroan Terbatas dan Perseroan Perorangan sama, yaitu pemegang saham tidak bertanggung jawab secara pribadi atas perikatan yang dibuat atas nama perseroan dan tidak bertanggung jawab atas kerugian perseroan melebihi saham yang dimiliki. Hal ini tercantum dalam Pasal 153J UU Cipta Kerja untuk Perseroan Perorangan. Namun ketentuan Pasal 153J tidak berlaku apabila:

a. persyaratan Perseroan sebagai badan hukum belum atau tidak terpenuhi;

b. pemegang saham yang bersangkutan, baik langsung maupun tidak langsung dengan iktikad buruk memanfaatkan Perseroan untuk kepentingan pribadi;

c. pemegang saham yang bersangkutan terlibat dalam perbuatan melawan hukum yang dilakukan oleh Perseroan; atau

d. pemegang saham yang bersangkutan, baik langsung maupun tidak langsung secara melawan hukum menggunakan kekayaan Perseroan, yang mengakibatkan kekayaan Perseroan menjadi tidak cukup untuk melunasi utang Perseroan.

Dalam Pasal 153J UU Cipta Kerja, memuat doktrin piercing the corporate veil, artinya membuka tirai perseroan, dimana tanggung jawab yang semula terbatas dibuka dan diterobos menjadi tanggung jawab tidak terbatas hingga kekayaan pribadi manakala terjadi pelanggaran, penyimpangan atau kesalahan dalam melakukan pengurusan perseroan. ${ }^{24}$ Konsekuensi hukumnya yaitu terhapusnya tanggung jawab terbatas pada pemegang saham. Prinsip piercing the corporate veil merupakan prinsip yang membenarkan penghapusan tanggung jawab terbatas pada pemegang saham dalam keadaan-keadaan tertentu.

\footnotetext{
${ }^{22}$ Hardiyono, Y. W., Ibid. hlm 1099.

${ }^{23}$ Yuwono, M. Y. (2015). Perkembangan Kewenangan Rapat Umum Pemegang Saham (RUPS) Perseroan Terbatas di Indonesia. Notarius, 8(2), 207-235. hlm. 213.

${ }^{24}$ Dewi, S. (2018). Mengenal Doktrin Dan Prinsip Piercing The Corporate Veil Dalam Hukum Perusahaan. Soumatera Law Review, 1(2), 380-399. hlm. 385.
} 
Penerobosan tanggung jawab terbatas pemegang saham melalui prinsip piercing the corporate veil dimaksudkan untuk mencegah terjadinya penyalahgunaan perlindungan hukum yang diberikankepada pemegang saham seperti tindakan dengan itikad buruk, lalai, ceroboh, bertentangan dengan kepentingan perusahaan serta membuat perusahaan mengalami kebangkrutan. ${ }^{25}$

Terkait pembuktian mengenai apa adanya itikad buruk yang dilakukan oleh pemegang saham dalam Perseroan Perorangan tampaknya sulit dilakukan hal ini dikarenakan hilang kedudukan komisaris dalam perseroan yang berfungsi untuk mengawasi jalannya perseroan untuk menghindari adanya itikad buruk dari satu pihak. Istilah "kepentingan pribadi" juga menjadi kontraproduktif mengingat badan hukum perorangan didirikan oleh satu orang yang secara alamiah akan melindungi harta pribadi sendiri. Meskipun adanya kewajiban dalam menyampaikan laporan keuangan kepada Kementerian Hukum dan HAM, hal tersebut tidak dapat dipastikan adanya pengawasan yang ketat. Pecampuran harta dalam suatu Perseroan UMK juga sangat sulit untuk dihindari, hal ini disebabkan perseroan dimaksud menjalankan aktivitas berdasarkan asas keluarga, ataupun asas ekonomi. Pada kondisi tersebut, batasan pertanggungjawaban akan semakin sulit, dalam hal pengelolaan Perseroan secara tidak profesional. ${ }^{26}$

\section{Kepastian Hukum Perseroan Perorangan akibat UU Cipta Kerja yang Inkonstitusional}

Pada tahun 2021, tepatnya 25 Nopember 2021, Mahkamah Konstitusi (MK) mengabulkan sebagian permohonan uji formil dan menyatakan UU Cipta Kerja inkonstitusional bersyarat melalui Putusan Mahkamah Konstitusi No 91/PUU-XVIII Tahun 2020. Dari 9 juri MK, 5 hakim mengabulkan permohonan judicial review, sedangkan 4 hakim menyatakan pendapat yang berbeda. UU Cipta Kerja dinyatakan inskonstitusional bersyarat karena pembentukannya yang bertentangan dengan UUD dan MK juga memerintahkan kepada pembentuk Undang-Undang untuk melakukan perbaikan dalam jangka waktu paling lama 2 (dua) tahun sejak putusan diucapkan. ${ }^{27}$ Hakim MK menggangap bahwa UU Cipta Kerja tidak jelas mengenai metodenya apakah bersifat revisi atau membuat Undang-Undang baru. Hakim MK juga menilai bahwa pembentukan UU Cipta Kerja tidak transparan kepada publik.

\section{Korelasi UMKM dengan UU Cipta Kerja}

Pedoman hukum terkait implementasi UMKM di Indonesia diatur dalam UndangUndang Nomor 20 Tahun 2008 Tentang Usaha Mikro, Kecil dan Menengah, Undang-undang Nomor 5 tahun 2007 tentang Penanaman Modal serta peraturan pelaksananya. Regulasi mengenai UMKM tesebar dalam berbagai peraturan perundang-undangan, sehingga berimplikasi pada sistem pemberdayaan UMKM yang terpecah, tidak komprehensif, dan

\footnotetext{
${ }^{25}$ Dewi, A. S. K. (2022). Karakteristik Perseroan Perorangan Sebagai Perseroan Yang Memenuhi Kriteria Untuk Usaha Mikro Dan Kecil. Yurispruden: Jurnal Fakultas Hukum Universitas Islam Malang, 5(1), 31-54. Hlm. 43.

${ }^{26}$ Sitorus, R. (2021). Eksistensi Perseroan Umk Dan Implikasi Hukumnya Terhadap Kepailitan Menurut Sistem Hukum Di Indonesia. Majalah Hukum Nasional, 51(1), 21-39. hlm. 34.

${ }^{27}$ Mahkamah Konstitusi Republik Indonesia. MK: Inkonstitusional Bersyarat, UU Cipta Kerja Harus Diperbaiki dalam Jangka Waktu Dua Tahun. https://www.mkri.id/index.php?page=web.Berita\&id=17816t, Diakses pada 20 Februari 2022.
} 
menghambat investasi. Regulasi yang mempengaruhi pemberdayaan UMKM, antara lain prosedur dan biaya perizinan memulai usaha, syarat kepemilikan saham minoritas dan pembayaran melalui sistem online. ${ }^{28}$ Hasil kajian Satgas Kamar Dagang dan Industri mengklasifikasi 11 (sebelas) klaster regulasi terkait investasi yang perlu dibenahi, salah satunya terkait kemudahan dan perlindungan UMKM serta kemudahan berusaha. ${ }^{29}$ Hal ini dukung dengan hasil survei yang dilakukan oleh Bank Indonesia tentang profil UMKM terkait penyebab kinerja UMKM yang masih rendah, salah satunya terkait kemudahan UMKM dalam memperoleh izin. ${ }^{30}$

Hadirnya UU Cipta Kerja merubah, menghapus serta menetapkan ketentuan baru usaha mikro kecil dan menengah. Pemberian kemudahan, perlindungan, dan pemberdayaan UMK dijadiikan prioritas dalam UU Cipta Kerja. Kemudahan yang diberikan ke UMKM, dijabarkan pada Bab V, dari Pasal 87 hingga Pasal 104. ${ }^{31}$ Pasal 87 UU Cipta Kerja yang merubah ketentuan pada Pasal 12 UU UMKM mengenai adanya pembebasan biaya ijin usaha dan keringanan biaya untuk usaha kecil. Pasal 91 UU Cipta Kerja mengenai kemudahan pada sektor perijinan bagi UMKM yang semakin mudah dan sederhana. Sebelum adanya UU Cipta Kerja, UMKM membuat badan hukum dalam bentuk Perseroan Terbatas, dimana akan melalui proses yang panjang dan rumit. Sejak adanya UU Cipta Kerja, Perseroan Peorangan dibentuk dalam susunan dan kepemilikan yang lebih sederhana sehingga akan memudahkan dan meringkan biaya para pelaku usaha.

\section{Implikasi Perseroan Perorangan terhadap UU Cipta Kerja yang Inkonstitusional}

Berdasarkan Putusan Mahkamah Konstitusi No. 91/PUU-XVIII/2020, UU Cipta Kerja tidak mempunyai kekuatan hukum mengikat secara bersyarat sepanjang tidak dilakukan perbaikan dalam kurun waktu 2 (dua) tahun sejak putusan ini diucapkan. Putusan ini juga menyatakan untuk menangguhkan segala tindakan/kebijakan yang bersifat strategis dan berdampak luas, serta tidak dibenarkan pula menerbitkan peraturan pelaksana baru yang berkaitan dengan UU Cipta Kerja. Oleh karena itu, UU Cipta Kerja akan tetap berlaku sampai dengan formasi perbaikan dalam periode yang ditentukan, serta formasi kriteria UMKM yang ada di dalamnya. Namun jika dalam waktu 2 (dua) tahun, pembentuk undangundang tersebut tidak dapat menyelesaikan revisi UU Cipta Kerja, maka UU Cipta Kerja akan dinyatakan inkonstitusional secara permanen dan UU UMKM dinyatakan sah kembali. $^{32}$

\footnotetext{
${ }^{28}$ Corputty, P. (2020). Omnibus Law Sebagai Alternatif Penyembuh Obesitas Regulasi Sektoral. Jurnal Saniri, 1(1), 44-61.hlm. 53.

${ }^{29}$ Rongiyati, S. (2019). Menata Regulasi Pemberdayaan UMKM Melalui Omnibus Law. Vol. XI, (23). hlm. 2.

${ }^{30}$ Khair, O. I., Widiatmoko, C., \& Simarmata, R. P. (2022). Analisis UU Cipta Kerja dan Kemudahan Berusaha Bagi UMKM. Syntax Literate; Jurnal Ilmiah Indonesia, 7(2), 2246-2263. hlm. 905.

${ }^{31}$ Sumampouw, W., Kurnia, K., \& Arrobi, I. R. (2021). Perlindungan Hukum Terhadap Usaha Mikro Kecil dan Menengah Pasca Pemberlakuan Undang-Undang Nomor 11 Tahun 2020 tentang Cipta Kerja. Jurnal de jure, 13(1). hlm. 36 .

${ }^{32}$ Hadiyati, N. (2022). Legal Implications Of Msme Regulation On The Conditionally Unconstitutional Job Creation Law. Jurnal Komunikasi Hukum (JKH), 8(1), 291-306. hlm. 303.
} 
Putusan tersebut menjadi perhatian publik karena di satu sisi dalam amar nomor 4, MK menyatakan UU Cipta Kerja masih berlaku, namun dalam amar nomor 7 memerintahkan penangguhan untuk tindakan dan kebijakan yang bersifat strategis dan berdampak luas. Secara umum, UU Cipta Kerja masih berlaku, namun ketika sifatnya strategis dan berdampak luas, maka keberlakuan UU Cipta Kerja harus ditangguhkan. Namun pembatasan perihal mana yang bersifat strategis dan berdampak luas tidak diuraikan secara jelas dan tegas sehingga menimbulkan kerancuan. ${ }^{33}$ Mengingat UU Cipta Kerja yang menyederhanakan puluhan regulasi diberbagai sektor, sudah tentu efeknya berdampak luas. Hal tersebut memunculkan pemahaman bahwa seluruh keberlakukan UU Cipta Kerja harus ditangguhkan karena bersifat strategis dan berdampak luas.

Disatu sisi UU Cipta Kerja ditangguhkan, di lain sisi aturan lama tidak berlaku karena UU Cipta Kerja masih ada, dari sini dapat diambil kesimpulan bahwa adanya kekosongan hukum sampai dengan UU Cipta Kerja berhasil direvisi. Jika UU Cipta Kerja tidak ditangguhkan dan masih tetap dilaksanakan hal ini akan bertentangan dengan putusan MK dan merupakan perbuatan melawan hukum. Namun jika UU Cipta Kerja berhasil direvisi seluruh sektor di berbagai bidang akan mengalami perluasan dan perkembangan yang signifikan. Perekonomian dan iklim usaha akan berkembang dengan pesat karena dengan kemudahan yang diberikan terkhusus UMK, akan sangat membantu para pelaku usaha yang semula terhambat akibat beberapa aspek. Tujuan utama dari UU Cipta Kerja itu sendiri, diprioritaskan untuk UMK akan terwujudkan sehingga hal ini berdampak positif untuk para pelaku usaha mikro dan kecil.

Tidak menutup kemungkinan jika UU Cipta Kerja tidak berhasil direvisi dalam jangka waktu 2 (dua) tahun, pemberian jangka waktu 2 (dua) tahun dinilai singkat karena UU Cipta Kerja itu sendiri mencakup puluhan regulasi. Sehingga Perseroan Perorangan yang telah berdiri memerlukan perlindungan hukum. Apabila ditinjau dari teori perlindungan hukum menurut Philipus M. Hadjon, dijelaskan bahwa perlindungan hukum bagi rakyat sebagai tindakan pemerintah yang bersifat preventif dan represif. ${ }^{34}$ Sembari UU Cipta Kerja di revisi, Perseroan Perorangan yang telah berdiri dapat melakukan perlindungan hukum dalam bentuk upaya preventif yaitu mengajukan keberatan sebelum suatu keputusan pemerintah mendapat bentuk yang definitif. Keberatan yang diajukan dapat berbentuk petisi maupun demo dengan prosedur yang benar. Jika upaya preventif telah dilakukan dan tidak mendapatkan hasil yang diharapkan sedangkan UU Cipta Kerja sudah direvisi dan diberlakukan kembali maka Perseroan Peorangan dapat melakukan upaya hukum berbentuk represif dengan mengajukan keberatan terhadap putusan MK.

\footnotetext{
${ }^{33}$ Batubara, M. I., Adi, E. A. W., \& Wirdyaningsih, W. (2022). Peran Notaris Dalam Pemanfaatan Ruang Bawah Tanah Untuk Sarana Jaringan Utilitas Terpadu Di Dki Jakarta. JISIP (Jurnal Ilmu Sosial dan Pendidikan), 6(1). hlm. 1977.

${ }^{34}$ Tirtakoesoemah, A. J., \& Arafat, M. R. (2020). Penerapan Teori Perlindungan Hukum Terhadap Hak Cipta Atas Penyiaran. Pena Justisia: Media Komunikasi Dan Kajian Hukum, 18(1). hlm. 5.
} 


\section{KESIMPULAN}

Berdasarkan analisis diatas dan dalam menjawab rumusan masalah yang telah diuraikan sebelumnya maka penulis dapat menarik sebuah kesimpulan yaitu sebagai berikut:

Pertama, dengan adanya UU Cipta Kerja, timbulnya badan hukum baru yaitu Perseroan Perorangan, beberapa kriteria pokok di dalamnya meliputi: definisi, pendirian, modal, direksi, perubahan serta pembubaran. Setelah dianalisis Perseroan Perorangan masih menimbulan celah hukum yang dapat mengakibatkan tidak terciptanya tujuan utamanya.

Kedua, Berdasarkan putusan No. 91/PUU-XVIII/2020, UU Cipta Kerja dinyatakan inkonstitusional dan diberi kurun waktu 2 (dua) tahun untuk merevisinya, dalam kurun waktu tersebut segala tindakan dan kebijakan yang bersifat strategis dan berdampak luas harus ditangguhkan. Ditangguhkan UU Cipta Kerja mengakibatkan adanya kekosongan hukum yang berakibat pada adanya ketidakpastian perseroan perorangan. Perseroan Perorangan yang telah berdiri dapat melakukan upaya hukum dalam bentuk preventif dan represif.

\section{DAFTAR PUSTAKA}

Abbas, D. (2018). Pengaruh modal usaha, orientasi pasar, dan orientasi kewirausahaan terhadap kinerja ukm kota makassar. Jurnal Minds: Manajemen Ide Dan Inspirasi, 5(1), 95-112.

Ariani, N. V., \& Narindrani, M. L. F. (2021). Legal Aspect of Individual Company for Micro and Small Business in Omnibus Law on Job Creation. In 2nd International Conference on Law and Human Rights 2021 (ICLHR 2021) (pp. 1-7). Atlantis Press.

Arief, A., \& Ramadani, R. (2021). Omnibus Law Cipta Kerja dan Implikasinya Terhadap Konsep Dasar Perseroan Terbatas. Al-Adalah: Jurnal Hukum dan Politik Islam, 6(2), 106-120.

Aprilia, I. S. (2020). Aspek Hukum Pemegang Saham dalam Perseroan dengan Satu Pemegang Saham (Single Share-holder)(Studi Komparasi Indonesia dengan China). SUPREMASI: Jurnal Hukum, 3(1), 1-14.

Batubara, M. I., Adi, E. A. W., \& Wirdyaningsih, W. (2022). Peran Notaris Dalam Pemanfaatan Ruang Bawah Tanah Untuk Sarana Jaringan Utilitas Terpadu Di Dki Jakarta. JISIP (Jurnal Ilmu Sosial dan Pendidikan), 6(1).

Corputty, P. (2020). Omnibus Law Sebagai Alternatif Penyembuh Obesitas Regulasi Sektoral. Jurnal Saniri, 1(1), 44-61.

Dewi, A. S. K. (2022). Karakteristik Perseroan Perorangan Sebagai Perseroan Yang Memenuhi Kriteria Untuk Usaha Mikro Dan Kecil. Yurispruden: Jurnal Fakultas Hukum Universitas Islam Malang, 5(1), 31-54.

Dewi, S. (2018). Mengenal Doktrin Dan Prinsip Piercing The Corporate Veil Dalam Hukum Perusahaan. Soumatera Law Review, 1(2), 380-399.

Gloria, M. (2021). Kepailitan Perseroan Perorangan dalam Undang-Undang Cipta Kerja. Jurnal Panorama Hukum, 6(1), 24-31. 
Hanoatubun, S. (2020). Dampak Covid-19 terhadap Prekonomian Indonesia. EduPsyCouns: Journal of Education, Psychology and Counseling, 2(1), 146-153.

Hardiyono, Y. W. (2021). Keabsahan dan Akibat Hukum Pendirian Perseroan Mikro dan Kecil yang didirikan Berdasarkan Undang-Undang Nomor 11 Tahun 2020 Tentang Cipta Kerja. Dinamika: Jurnal Ilmiah Ilmu Hukum, 27(8), 1086-1101.

Isnaeni, D. (2021). Peran Notaris Dalam Pendirian Pt Usaha Mikro Dan Kecil. Jurnal Hukum Dan Kenotariatan, 5(2).

Jaya, F. (2021). Potensi Konflik Kepentingan dalam Pendirian Badan Hukum Perorangan Pasca Revisi Undang-Undang Perseroan Terbatas dalam Omnibus Law. Kosmik Hukum, 21(2), 115-123.

Khair, O. I., Widiatmoko, C., \& Simarmata, R. P. (2022). Analisis UU Cipta Kerja dan Kemudahan Berusaha Bagi UMKM. Syntax Literate; Jurnal Ilmiah Indonesia, 7(2), 2246-2263.

Manurung, O. T. (2016). Tugas Dan Tanggung Jawab Dewan Komisaris Sebagai Organ Perseroan Terbatas Menurut Undang Nomor 40 Tahun 2007. Lex Privatum, 4(7).

Matompo, O. S. (2020). Konsep Omnibus Law Dan Permasalahan Ruu Cipta Kerja.

Rechtstaat Nieuw, 5(1).

Pangesti, S. (2021). Penguatan Regulasi Perseroan Terbatas Perorangan Usaha Mikro Dan

Kecil Dalam Mendukung Pemulihan Ekonomi Masa Pandemi Covid-19. Jurnal Rechts Vinding: Media Pembinaan Hukum Nasional, 10(1), 117. hlm. 123.

Prabu, A., Harahap, I. N., Ernasari, N., Primagani, T., Nirpana, B., Andriyas, I., \& Susanto, S. (2020). Kemudahan Berusaha Dalam Cluster Omnibus Law. Jurnal Lex Specialis, 1(2).

Rongiyati, S. (2019). Menata Regulasi Pemberdayaan UMKM Melalui Omnibus Law. Vol. XI, (23).

Sitorus, R. (2021). Eksistensi Perseroan Umk Dan Implikasi Hukumnya Terhadap Kepailitan Menurut Sistem Hukum Di Indonesia. Majalah Hukum Nasional, 51(1), 21-39.

Sulfati, A. (2018). Efektivitas Pengembangan Usaha Mikro Di Indonesia. Jurnal Aplikasi Manajemen, Ekonomi dan Bisnis, 2(2), 59-69.

Sumampouw, W., Kurnia, K., \& Arrobi, I. R. (2021). Perlindungan Hukum Terhadap Usaha Mikro Kecil dan Menengah Pasca Pemberlakuan Undang-Undang Nomor 11 Tahun 2020 tentang Cipta Kerja. Jurnal de jure, 13(1).

Tan, D. (2021). Metode Penelitian Hukum: Mengupas Dan Mengulas Metodologi Dalam Menyelenggarakan Penelitian Hukum. Nusantara: Jurnal Ilmu Pengetahuan Sosial, 8(8), 2463-2478.

Yuwono, M. Y. (2015). Perkembangan Kewenangan Rapat Umum Pemegang Saham (RUPS) Perseroan Terbatas di Indonesia. Notarius, 8(2), 207-235.

Zulhidayat, M., \& Aslamiyah, M. (2021). Pertanggungjawaban Pemegang Saham Perseroan Perorangan dalam Hal Perseroan Perorangan Mengalami Kerugian Berdasarkan UU No. 11 Tahun 2020 Tentang Cipta Kerja. Rechtsregel: Jurnal Ilmu Hukum, 4(1), 119-133. 
Ishaq, I. (2017). Metode Penelitian Hukum dan Penulisan Skripsi, Tesis, serta Disertasi. Bandung: Alfabeta.

Kementerian Koperasi dan Usaha Kecil dan Menangah (UKM). Perkembangan Data Usaha Mikro, Kecil, Menengah (UMKM) dan Usaha Besar (UB) tahun 2017-2018. http://www.depkop.go.id/uploads/laporan/1580223129_PERKEMBANGAN\%20DATA \%20USAHA \%20MIKRO,\%20KECIL,\%20MENENGAH\%20(UMKM)\%20DAN\%20U SAHA\%20BESAR\%20(UB)\%20TAHUN\%202017\%20-\%202018.pdf, Diakses pada 12 Februari 2022.

Mahkamah Konstitusi Republik Indonesia. MK: Inkonstitusional Bersyarat, UU Cipta Kerja Harus Diperbaiki dalam Jangka Waktu Dua Tahun. https://www.mkri.id/index.php?page=web.Berita\&id=17816t, Diakses pada 20 Februari 2022.

Undang-Undang Nomor 11 Tahun 2020 tentang Cipta Kerja

Undang-Undang Nomor 40 Tahun 2007 tentang Perseroan Terbatas

Undang-undang Nomor 20 Tahun 2008. Usaha Mikro, Kecil, dan Menengah

Peraturan Pemerintah Nomor 7 Tahun 2021 tentang Kemudahan, Pelindungan, dan Pemberdayaan Koperasi dan Usaha Mikro, Kecil, dan Menengah

Peraturan Pemerintah Nomor 8 Tahun 2021 tentang Modal Dasar Perseroan Serta Pendaftaran Pendirian, Perubahan, Dan Pembubaran Perseroan Yang Memenuhi Kriteria Untuk Usaha Mikro Dan Kecil 